http://www.nbuv.gov.ua/portal/soc_gum/Ppps/2010_32/ files/215-219.pdf 6. Рамкова програма 3 німецької мови для професійного спілкування для вищих навчальних закладів України / С. М. Амеліна, Л. С. Аззоліні та ін. - К. : Ленвіт, 2006. - 90 с. 7. Рамкова програма 3 німецької мови для професійного спілкування для вищих навчальних закладів України / С. М. Амеліна, В. А. Гаманюк та ін. - К. : Ленвіт, 2014. - 136 с. 8. Програма 3 англійської мови для професійного спілкування / Г. Є. Бакаєва, О. А. Борисенко, І. І. Зуєнок та ін. - К. : Ленвіт, 2005. - 119 с. 9. Програма 3 англійської мови для університетів (інститутів): п'ятирічний курс навчання / С. Ю. Ніколаєва, М. І. Соловей та ін. / Київ : Британська Рада, Київ. держ. лінгв. ун-т, 2001. -245 с.

УДК 37.091 .33

Анна Смельова

\title{
ВИВЧЕННЯ ДОСВІДУ ОРГАНІЗАЦІЇ ТРУДОВОГО НАВЧАННЯ В НАРОДНИХ ШКОЛАХ КАТЕРИНОСЛАВЩИНИ В СУЧАСНІЙ ПРАКТИЦІ ВИЩОЇ ШКОЛИ
}

Ємельова А. П. Вивчення досвіду організації трудового навчання в народних школах Катеринославщини в сучасній практиці вищої школи.

У статті розглянуто історико-педагогічний досвід організації трудового навчання в народних школах Катеринославської губернії (в кінці XIX - на початку XX століття). Окреслено етапи розвитку трудового навчання в народних школах Катеринославщини. Описано навчально-методичний комплекс, який сприятиме підвищенню ефективності професійної підготовки студентів ВНЗ у сучасних умовах розвитку суспільства.

Ключові слова: трудове навчання, народна школа, навчально-методичний комплекс.

Емелёва А. П. Изучение опыта организации трудовой учебы в народных школах Екатеринославщины в современной практике высшей школы.

В статье рассмотрен историко-педагогический опыт организации трудового обучения в народных школах Екатеринославской губернии (в конце XIX - начале XX века). Определены этапы развития трудового обучения в народных школах Екатеринославщины. Описан учебно-методический комплекс для повышения эффективности профессиональной подготовки студентов вузов в современных условиях развития общества.

Ключевые слова: трудовое обучение, народная школа, учебно-методический комплекс.

Yemeleva A. П. Study of experience of organization of labour studies is in folk schools of Katerinoslavshchina in modern practice of higher school.

The article discusses the historical and pedagogical experience of labor education in public schools of Katerynoslavska province (late XIX - early XX century). The educationalmethodical complex named "The Development of labor studies in folk high schools of Katerynoslavshchina (the end of XIX - the beginning of XX century)» was made according to the results of the research to deepen the knowledge of theory and history of pedagogy, ethnology, history of culture.

Key words: employment training, public school, teaching complex. 
Освіта $є$ і залишатиметься визначальною задля закладення грунтовних основ індивідуального, соціального, національного розвитку людини. Шлях до збереження українською нацією власної індивідуальності, в умовах ії поступового входження до світової соціокультурної спільноти, полягає в оновленні процесів базового навчання та виховання підростаючих поколінь, формування в дітей 3 раннього віку національної гідності, розуміння специфіки української культури, бажання зберігати та збагачувати національну скарбницю.

Дослідник Є. Хриков наголошує, що «у педагогічній науці завжди співіснують дві різноспрямовані тенденції - на збереження та розвиток національних традицій в освіті та на зближення світових моделей науки та освіти. Орієнтація на збереження національних традицій в освіті є однією з умов формування національної свідомості громадян, збереження національної самобутності та незалежності» [3, с. 23].

Важливою умовою успішної реалізації завдань педагогічної освіти $\epsilon$ не лише пошук нових дієвих теоретичних та практичних розробок, а й вивчення, узагальнення i творче переосмислення історико-педагогічного досвіду. Історико-педагогічна обізнаність дозволяє майбутньому педагогу орієнтуватися у складному розмаїтті сучасних підходів до навчального процесу, збагачує палітру наявних засобів, стимулює свободу педагогічної творчості та розвиває критичність мислення. У зв'язку з цим набуває значення і пошук дієвих шляхів донесення найкращих здобутків трудового навчання минулого Катеринославського регіону, багатого вітчизняного педагогічного досвіду до сучасного вчителя у процесі його професійної підготовки.

3 огляду на вищезазначене цікавим у науково-дослідницькому плані $є$ період кінця XIX - початку XX століття, що характеризується «розмежуванням педагогічної думки», «породженням цілої плеяди відомих і видатних педагогів, діячів освіти, мислителів» (О. Сухомлинська), розбудовою нових освітньо-виховних систем, зокрема народної школи. Саме в цей період у контексті розв'язання освітніх проблем педагогічна громадськість репрезентувала дієві шляхи, способи трудового виховання та навчання особистості.

Процес інтеграції України до європейського простору зумовлює необхідність модернізації системи освіти та приведення ії у відповідність до світових стандартів. Нины актуальною є проблема зближення змісту і якості освіти в різних країнах Європи. Під упливом такої концептуальної ідеї відбувається вдосконалення навчальних планів, програм, підручників та іншого навчально-методичного забезпечення шкільних предметів.

Якість освіти нерозривно пов'язана з ії виховним потенціалом. Школа має не тільки озброїти учнів знаннями з основ наук, що відповідають вимогам часу, але й підготувати їх до праці, свідомого вибору продовження освіти та майбутньої професії. Головним складником модернізації освіти є посилення ролі дисциплін, які забезпечують успішну соціалізацію підростаючого покоління. Пріоритетною 3-поміж них, безумовно, $є$ освітня галузь «Технологія». Успіх трудового виховання молодого покоління вбачається в об'єднанні зусиль загальноосвітніх закладів, сім’ї, громадськості.

Учитель не стільки контролює вивчення і відтворення учнем певних знань i відповідних умінь, а допомагає й підтримує його у процесі засвоєння і застосування нових знань на практиці з урахуванням його особистих здібностей та природних нахилів.

Відповідно до цього змінюються традиційні підходи до змісту освіти, і зокрема, в трудовому навчанні учнів. Так, сучасний розвиток суспільства та виробництва потребує не лише навчати учнів запам'ятовувати і відтворювати техніко-технологічні знання та прийоми роботи інструментом, а й застосовувати такі знання та вміння на 
практиці - через розв'язання творчих завдань (виконання навчальних i творчих проектів), формування відповідного досвіду.

Слід зазначити, що трудове навчання як компонент освітньої галузі «Технологія» зазнає змін з розвитком науково-технічного прогресу, модернізацією сфери техніки і технологій. За таких змін необхідно враховувати історичний досвід педагогічної науки і практики.

Столітній досвід народних закладів освіти Катеринославщини свідчить, що в попередні роки визначено орієнтир на виховання працелюбної, творчої особистості, яка була б підготовлена до трудової діяльності, що зумовило відкриття ремісничих відділень та класів, уведення необов'язкових предметів трудового спрямування тощо.

Проведене дослідження надало змогу виокремити етапи розвитку трудового навчання в народних школах Катеринославської губернії кінця XIX - початку XX століття.

І етап - становлення - 70-80 pp. ХІХ століття: видатними педагогами розроблено ідеї введення уроків трудового спрямування в народні школи. Ці ідеї стали підгрунтям запровадження 3 70-х років ремесел, рукоділля, ручної праці, сільськогосподарських знань у народних школах.

II - нормативно-правове та навчально-методичне забезпечення - 1884 - 1900 pp.: Міністерство народної освіти видало низку положень, циркулярів, правил про організацію трудового навчання в різних типах народних шкіл. У цей період розроблено типові навчальні плани та програми, видано книжки, підручники 3 трудового навчання.

III етап - подальший розвиток - 1901-1917 pp. XX століття, що характеризується збільшенням кількості шкіл, у яких викладалося трудове навчання, а також кількості учнів, які вивчали ручну працю, рукоділля, садівництво, городництво тощо. Цей період визначний тим, що громадськістю визнано доцільність і корисність уроків трудового навчання. Представники земських установ, дворяни, підприємці, громадські діячі сприяли розвиткові трудового навчання, асигнуючи кошти, благодійні пожертви на відкриття та діяльність ремісничих відділень та класів, улаштування садів, городів, пасік при народних школах.

Слід зазначити, що в народних школах Катеринославської губернії, незважаючи на наявність офіційних планів та програм, припускалася можливість творчого підходу до викладання уроків трудового спрямування.

Належна увага приділялася розвитку в учнів художньо-естетичного смаку. Задля цього в школах проводили заняття 3 малювання та ручної художньої праці. Практичні заняття з малювання чергувалися з лекціями-бесідами, під час яких обговорювалися репродукції художніх творів видатних митців [1].

Цікавим і корисним складником трудового навчання в кінці XIX століття було проведення екскурсій до визначних історичних пам'яток, храмів, де учні мали змогу ознайомитися 3 витворами декоративно-прикладного мистецтва. Також організовувалися екскурсії Дніпровськими порогами, на місця будування мостів, до місцевих заводів, фабрик задля ознайомлення учнів з процесом виробництва [1].

Уважаємо, що досвід використання екскурсійного методу Катеринославського регіону досліджуваного періоду варто використовувати у практиці загальноосвітніх шкіл. Особливу роль варто відводити екскурсіям на місцеві виробництва, 3 подальшим відтворенням побаченого засобами рольових ігор.

Аналізуючи зміст занять з ручної праці, ремесел, рукоділля в народних школах Катеринославщини кінця XIX - початку XX століття, виявлено, що уроки трудового 
спрямування проводилися 3 використанням інструментів та матеріалів. Учні виготовляли різноманітні вироби зі слюсарно-ковальського ремесла (лінійки, відкрутки, циркулі, кронциркулі, прості та складні гайкові ключі, різноманітні ножі, молотки, різні машини для подрібнення цукру, ліжка тощо) зі столярно-токарного ремесла (столи та табурети, віяльні станки, кухонні столи та шафи, розкладні столи, комоди тощо) [4].

Навчально-матеріальна база, на якій відбувається трудова підготовка учнів, у деяких школах є застарілою. У більшості випадків обладнання навчальних майстерень виходить 3 ладу й не оновлюється, а придбати нове зазвичай немає коштів. Слід зазначити, що необхідними інструментами та матеріалами народні школи забезпечували губернське та повітові земства. Значну допомогу в матеріальному забезпеченні шкіл надавали меценати та благодійники Катеринославщини. Сподіваємося на відродження традиції меценатства, оскільки не всі сучасні класи трудового навчання оснащені необхідними інструментами та обладнанням.

Проаналізувавши зміст трудового навчання в народних школах, зазначимо, що поширеною формою була організація сільськогосподарської практики. Учні сільських шкіл на практиці ознайомлювалися 3 живою природою в лісі, господарствах, садах, працювали на городах та присадибних ділянках, вели щоденники спостережень. Учні міських шкіл займалися озелененням парків (насаджували дерева та кущі, підкопували та поливали дерева).

На нашу думку, виробнича практика в загальноосвітніх школах має передбачати різні види трудової діяльності, чого прагнули педагоги Катеринославщини кінця XIX - початку XX століття.

Праця для учнів $є$ могутнім джерелом пізнання і розвитку, тому вважаємо обов'язковим залучення учнів до предметно-перетворювальної діяльності, що передбачає використання простих i доступних матеріалів. Робота 3 різними матеріалами розширюватиме уявлення учнів про навколишній світ, а ручна праця сприятиме розвитку сенсомоторики, координації рухів, гнучкості, точності.

У народних школах на заняттях 3 трудового навчання особлива увага приділялася розвитку в учнів самостійності в роботі. Вважаємо, що вміння планувати роботу, розробляти технічну документацію, здійснювати самоконтроль якості виконуваних операцій і виробів сприятиме розвитку самостійності в роботі.

Значне місце у трудовій діяльності учнів слід відводити вивченню традиційних народних ремесел, промислів, декоративно-прикладному мистецтву. Етнографічні матеріали, що відтворюють заняття, культуру, побут, звичаї, ремесла, декоративноприкладне мистецтво катеринославців експонуються у Національному краєзнавчому музеї імені Д. Яворницького. Цікавим для учнів уважаємо ознайомлення 3 технологією виготовлення виробів декоративно-прикладного мистецтва кінця XIX початку XX століття.

3-поміж засобів трудового виховання в досліджуваний період чільне місце посідала народна педагогіка, якій відводилася роль «фольклорної материнської школи», «школи життя». Визнаючи працю основою життя, стрижнем формування моральних якостей особистості, народна педагогіка створила оригінальну систему виховання працелюбства, характерною ознакою якої стало те, що безпосередній участі дитини у продуктивній праці передувала грунтовна психологічна підготовка, мотивація трудових дій, формування ціннісних орієнтацій. Цьому сприяли колискові пісні, «потєшки», обрядовий фольклорний календар, казки, прислів'я, приказки, загадки, народні іграшки, які розкривали красу i значущість праці, звеличували 
людину працьовиту, виховували пошану до людини-трудівника, стимулювали соціальну активність дитини.

Рекомендуємо вивчати народні звичаї і традиції, проводити трудові свята й обряди (свято першої борозни, свято врожаю, обжинки тощо), через образноемоційний, інтелектуально-пізнавальний та морально-дієвий компоненти яких відбувається виховання старанності, дисциплінованості, наполегливості, охайності, відповідальності у праці.

Узагальнення та вивчення накопиченого продуктивного досвіду 3 організації трудового навчання на дібраних історично-набутих зразках Катеринославщини кінця XIX - початку XX століття доцільно здійснювати за такими напрямками:

- аудиторна та позааудиторна робота 3 майбутніми вчителями 3 вивчення спецкурсу «Розвиток трудового навчання в народних школах Катеринославщини (кінець XIX - початок XX ст.)»;

- уведення змістових модулів до курсу «Історія педагогіки» та «Теорія й методика технологічної освіти»;

- робота зі студентською проблемною краєзнавчою групою, завданням якої $\epsilon$ розвиток та зміцнення інтересу студентів до краєзнавчої діяльності;

- формування мотивації до використання краєзнавчих знань у професійній діяльності засобами музейної педагогіки;

- знайомство 3 розмаїттям культурної спадщини Катеринославського регіону, історичними фактами, декоративно-прикладним мистецтвом;

- вивчення діяльності почесних громадян у галузі народної освіти та розвитку трудового навчання; формування національної гордості за рідний край.

Такий підхід до розв'язання складних завдань виховання підростаючого покоління, основою якого $є$ глибоке осмислення й усвідомлення історикопедагогічного досвіду, може забезпечити реалізацію освітньо-виховної мети сучасної педагогічної освіти, сприятиме зростанню освітнього та культурного потенціалу суспільства.

Проведене дослідження надало змогу розробити навчально-методичний комплекс «Розвиток трудового навчання в народних школах Катеринославщини (кінець XIX - початок XX ст.)» [2], який грунтується на регіональному компоненті та відображає у змісті та структурі освіти соціокультурну своєрідність областей (специфіку їх історії, культури, національних традицій тощо).

Розроблений навчально-методичний комплекс зорієнтований на поглиблення знань, умінь та навичок майбутніх фахівців у галузі педагогічної та технологічної освіти, узагальнення й творче використання позитивного історико-педагогічного досвіду з розвитку трудового навчання в народних школах Катеринославщини в кінці XIX - початку XX ст. у діяльності сучасної національної школи.

У навчально-методичному комплексі подано програму спецкурсу та навчальнометодичне забезпечення, що передбачає тематику й перелік основних питань і завдань для самоконтролю до лекційних та практичних занять, індивідуальні завдання творчого та дослідницького характеру, методичні рекомендації до виконання самостійної роботи, список використаних джерел. Навчально-методичний комплекс рекомендується для практичного використання у процесі підготовки фахівців педагогічного профілю, адресований викладачам, студентам, учителям-практикам, аспірантам і здобувачам.

Отже, можна зробити висновок, що впровадженню в сучасну систему національної освіти уроків трудового навчання сприяла діяльність багатьох поколінь 
відомих вітчизняних педагогів, учителів-практиків, організаторів трудової підготовки Катеринославщини. У кінці XIX - на початку XX століття були накопичені цінні ідеї, підходи для осмислення і вивчення досвіду у практиці вищої педагогічної школи. Розроблений спецкурс та методичне забезпечення уможливить використання окресленого історико-педагогічного досвіду 3 розвитку трудового навчання Катеринославщини в кінці XIX - на початку XX століття.

\section{Література}

1. Державний архів Дніпропетровської області. Ф. 11, оп. 1, Спр. 137. 2. Ємельова А. П. Розвиток трудового навчання в народних школах Катеринославщини (кінець XIX - початок XX століття): навч.-метод. комплекс / А. П. Смельова. - Кривий Ріг, 2013. - 89 с. 3. Методологічні засади педагогічного дослідження: [монографія] / авт. кол. : Є. М. Хриков, О. В. Адаменко, В. С. Курило та ін.; за заг. ред. В. С. Курила, С. М. Хрикова; Держ. закл. «Луган. нац. ун-т імені Тараса Шевченка». - Луганськ : ДЗ «ЛНУ імені Тараса Шевченка», 2013. - 248 с. 4. Отчет Екатеринославской Губернской Земской Управы за 1903 год, Екатеринослав: Типография Губернского Земства. - 1904. - 197 с.

УДК 37.014 .6

олена Кухарук

\section{ГОТОВНІСТЬ ДО МОНІТОРИНГУ ЯК ПЕДАГОГІЧНА ПРОБЛЕМА}

Кухарук О. В. Готовність до моніторингу як педагогічна проблема.

У статті висвітлено проблему готовності майбутніх педагогів до моніторингу. Здійснено грунтовне дослідження основних підходів до визначення сутності поняття «готовність» на основі аналізу психолого-педагогічної літератури. Встановлено сутність поняття «готовність до моніторингу». Виокремлено та охарактеризовано шість взаємопов'язаних структурних компонентів готовності до моніторингу: мотиваційний, науково-теоретичний, когнітивний, оціночний, праксикологічний та психологічний.

Ключові слова: готовність, готовність до моніторингу, мотиваційний, науковотеоретичний, когнітивний, оціночний, праксикологічний та психологічний компоненти.

Кухарук О. В. Готовность к мониторингу как педагогическая проблема.

В статье освещена проблема готовности будущих педагогов к мониторингу. Осуществлено детальное исследование основных подходов к определению сущности понятия «готовность» на основе анализа психолого-педагогической литературы. Установлено сущность понятия «готовность к мониторингу». Выделены и охарактеризованы шесть взаимосвязанных структурных компонентов готовности к мониторингу: мотивационный, научно-теоретический, когнитивный, оценочный, праксикологичний и психологический.

Ключевые слова: готовность, готовность к мониторингу, мотивационный, научно-теоретический, когнитивный, оценочный, праксикологичний и психологический компоненты.

Kukharuk O. V. Readiness to monitoring as a pedagogical problem.

The article deals with the problem of future teachers to monitor. Conducted thorough research of the main approaches to defining the essence of the concept of «readiness» based 